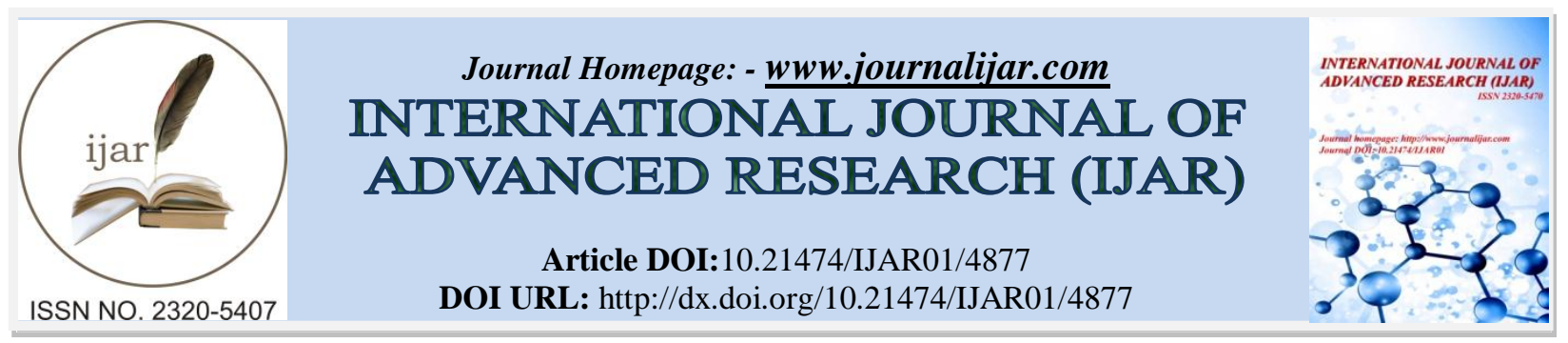

RESEARCH ARTICLE

\title{
ARE MOBILE RADIATIONS HARMFUL FOR BACTERIA? A CASE STUDY.
}

\author{
K.Biswas $^{1}$, A. K. Nayek ${ }^{1}$, J.Basu ${ }^{2}$, A. Ghosh ${ }^{1}$ and P. Giri ${ }^{3}$. \\ 1. Department of Physics, Dum Dum Motijheel College. \\ 2. Department of Microbiology, Dum Dum Motijheel College,. \\ 3. Department of Botany, Dum Dum Motijheel College.
}

\section{Manuscript Info}

(........................

Manuscript History

Received: 18 May 2017

Final Accepted: 20 June 2017

Published: July 2017

\section{Abstract}

As a cascading effect of electronic revolution and modernization of civilization use of cell phones and related other accessory gadgets emitting low frequency microwaves are increasing day by day. Though many reports are available on the effect of electromagnetic radiation of such kind on animal and plant system but its effect on microbial system is to some extent bewildering. In this article using $E$. coli as a model organism the effect of mobile waves of different frequencies on the growth has been tested. The aim of this experiment is to prove whether the mobile frequencies are actually harmful or risk-free to microbes using E. coli as a case study.

Copy Right, IJAR, 2017,. All rights reserved.

\section{Introduction:-}

In the present century remarkable progress has taken place in the Telecommunication services. The service network is not only restricted to urban area but it has wide spread existence in rural areas. As a consequence of such extension degree of emission of electromagnetic radiation is escalating towards its climax causing the microorganisms of the nature become liable to get more exposition towards it. Many of such microorganisms are beneficial and some are harmful or detrimental. Very scanty reports are available to explain at what extent such beneficial microbial wealth are being affected due to persistent exposition of wave frequencies coming out from mobile tower, cell phone and many such other low frequency electromagnetic radiation emitting devices. Being taken its position at the low frequency level of electromagnetic spectrum mobile wave is considered less harmful by different telecom service provider. Such service providers include different Government and private entrepreneurs.

According to World Health Organizations (WHO) the radiations coming out from telecom associated services belong to the category of radiofrequency and it ranges from $10 \mathrm{MHz}$ to $300 \mathrm{GHz}$. The cell phones generally radiate the microwave frequencies that ranges from $0.8 \mathrm{GHz}$ to $1.9 \mathrm{GHz}$. Now a day some companies manufacture cell phones that emit microwave radiation upto $2.4 \mathrm{GHz}$.

So far reports of investigation available in this field are to some extent incomprehensible. In the view of Physical and Engineering Sciences the microwave radiation is incapable of inducing bioeffects other than heating ${ }^{1}$. In microbial system the effect of microwave radiation depends upon the microwave frequency and the total energy absorbed by the microorganisms. In general, low frequency of microwaves enhances the growth of microorganisms while the high frequency and energy of same type of radiation destroy the microorganisms ${ }^{2}$. The microwave radiation and its profound electromagnetic effect on the alteration of cell morphology at the frequency of $18 \mathrm{GHz}$ and at a temperature below $40^{\circ} \mathrm{C}$ have been established in $E$. coli ${ }^{3}$. The growth rate of the same bacterium grown under 
anaerobic conditions also has been shown to be decreased in presence of glucose as a substrate under coherent electromagnetic irradiation of extremely high frequency $\left(45-53 \mathrm{GHz} \text { ) of low intensity (flux capacity } 0.06 \mathrm{~mW} / \mathrm{cm}^{2}\right)^{4}$. The electromagnetic waves emitted from mobile phones also reported to suppress the growth of micro organisms ${ }^{5}$. Such observation corroborates with the findings that the active exposure of radiofrequency fields (800 to $1800 \mathrm{MHz}$ ) transmitted and received by mobile phones cause consistent rise of temperature at the cellular level by $1^{0} \mathrm{C}$ or more which might be responsible to cause metabolic impairment and subsequent retardation of their growth ${ }^{6}$. The antimicrobial activity of low frequency electromagnetic energy could be substantiated by their application in food processing industry on the basis of the interaction of such distinctive energy with the biological materials ${ }^{7}$. Through further study it has been revealed that the survival rate of the bacterium (E.coli) though not altered due to the effects of low frequency electromagnetic radiation but some significant cellular and molecular changes are observed ${ }^{8}$. Such changes might be responsible for biostimulation of cultures ${ }^{9}$. Such stimulatory effects have immense role in Biotechnology, Biofuel and Bioenergy application. The bisostimulatory effect leading to the activation of growth of E. coli has also been demonstrated ${ }^{10}$. The viability of Staphylococcus aureus in terms of Colony Forming Unit (CFU) has been shown to be reduced due to the resonant effects of Extremely Low Frequency (ELF) Pulsed Electromagnetic Field (PEMF) radiation ${ }^{11}$. Information is also available that the microwave radiation may cause differential damage in bacterial cells by changing the cell wall structure. Such structural damages in cell wall could be studied through electron microscopic observation in E.coli .It is interpreted that change in wall structure may lead to the inactivation of cells without undergoing lyses. Hence no significant density reduction was observed in the suspension though viable count is reduced ${ }^{12}$. Hence, to get a clear and confirm effect of mobile waves on microbes the model organism E.coli was irradiated artificially in a controlled environment by mobile waves of different frequencies for a definite time period.

\section{Materials and Methods:-}

Overnight E.coli culture suspension in culture tube was used as experimental material for irradiation. Nutrient broth (NB) was used as culture medium for growth of the bacterium. $10 \mathrm{ml}$ of NB was taken in each of the twenty two culture tubes. To each of the culture tube $0.1 \mathrm{ml}$ overnight grown E.coli suspension was added except one which was kept for blank control. Out of twenty one inoculated culture tubes three were treated as control. Remaining eighteen tubes were used for irradiation treatment. Total six different frequencies of waves $(0.5 \mathrm{GHz}, 0.9 \mathrm{GHz}$, $1.9 \mathrm{GHz}, 2.4 \mathrm{GHz}, 3.0 \mathrm{GHz}$ and $3.8 \mathrm{GHz}$ ) were used for irradiation. For each frequency of wave three inoculated culture tubes were irradiated. The irradiation was made in a $3 \mathrm{~m}$ shielded semi anechoic chamber.

The overnight grown culture tubes carrying bacterial suspension were irradiated for 30 mins duration from an antenna located at the distance of 3.0 meters. During irradiation antenna input was maintained $20 \mathrm{dBm}$. Biconilog antenna was used for irradiation of the frequency of $0.5 \mathrm{GHz}$ and $0.9 \mathrm{GHz}$ and for $1.9 \mathrm{GHz}$ and above horn antenna was used (Fig 4).

Immediately after irradiation for each frequency the bacterial suspension was serially diluted until it reaches $10^{-6}$. Pour plate technique was then followed to grow the culture in a solid agar plate. Multiple replicas for each dilution were prepared and the plates were incubated at $37^{\circ} \mathrm{C}$ temperature for $18-24$ hours in a BOD incubator. Total number of Colony Forming Units (CFUs) was counted. The quantification of organisms per ml of suspension was measured by using the following formula:

$\mathrm{CFU} / \mathrm{ml}=$ No of visible colonies $\mathrm{x}$ dilution factor

The growth of the bacteria in the suspension was measured simultaneously in terms of optical density (OD) using UV visible spectrophotometer at $600 \mathrm{~nm}$.

\section{Results and Discussion:-}

As a preliminary study we observed and report that microwaves of lower frequencies released from different telecom devices seems to be not harmful for E.coli though, slight retardation of growth was measured against the frequency exposure less than $1 \mathrm{GHz}$. The results presented in the Table 1 reveals that lower microwave frequencies which are constantly being emitted from cell phones and other related gadgets in general are growth stimulatory in nature. Such frequencies of waves do not have enough potentialities for significant growth inhibition of E.coli. In our investigation we noticed that the bacterial growth in terms of increase in the number of colony forming units is steadily rising with the increase in frequency. This increase in the number of CFU attains its highest proximity at the frequency of $2.4 \mathrm{GHz}$ wherefrom it decreases and follows downward magnitude though the value is still greater than the control. The same growth pattern also corroborates when growth is expressed in terms of optical density (Fig 
1\&3). To substantiate the coincidence of growth measurement in terms of cfu and optical density graphical representation has been given in Fig 2 considering $1 \mathrm{OD}$ unit value is equal to approximately $10^{9}$ cells $/ \mathrm{ml}{ }^{13}$. Thus it could be concluded that the growth enhancing ability of low frequency microwaves is bio stimulatory in nature. Such stimulatory effects might be due to increase in penetrating ability of the low frequency microwaves into the bacterial cells causing certain gene activation. Such genes may be the regulatory genes of cell division cycles which expedite the check points of the cell cycle or other genes related to the metabolic process of cells.

Further investigation in this regard is essential to explain the exact reason behind the enhanced growth rate of bacterial culture. The declining trend of growth after the frequency of $2.4 \mathrm{GHz}$ corroborates the fact of inactivation of $E$. coli cells upon exposure to higher frequency. When cells are exposed to $18 \mathrm{GHz}$ frequency of $1500 \mathrm{KW} / \mathrm{m}^{2}$ energy, it causes inactivation of E.coli cells as a result of maximum increase in the porosity of plasma membrane. Thus it could be expected that higher frequency exposure might cause increase in the porosity of cell membrane leading to their inactivation ${ }^{14}$. The study of structural changes of the bacterial cell membrane upon higher frequency exposure could thus be an effervescent topic of investigation.

Merely through the study of the effect of low frequency electromagnetic radiation on the model organism E.coli it could not be reached to a general conclusion that such radiation is universally risk-free to all beneficial organisms. Sufficient trials must be performed by changing energy content of the waves, by changing the types of organism and also by changing the time of exposure to reach a consolidated decision regarding the effect of mobile waves on the microorganisms. Nevertheless, our findings may be considered as an index for the telecom service provider who can think of the increase of the frequency of radiation of the source tower at least upto $3.4 \mathrm{GHz}$ for betterment or upliftment of their service quality, though the standardization requires more investigation on the organisms other than E.coli and animal systems as well.

Table 1:-Effect of different frequencies of mobile waves on the growth of E.coli.

\begin{tabular}{|c|c|c|c|c|c|}
\hline $\begin{array}{c}\text { Name of the } \\
\text { organism }\end{array}$ & $\begin{array}{c}\text { Frequencies } \\
\text { used for } \\
\text { exposure }\end{array}$ & $\begin{array}{c}\text { Distance of the } \\
\text { sample from } \\
\text { radiation source( m) }\end{array}$ & $\begin{array}{c}\text { Exposure } \\
\text { time (min) }\end{array}$ & $\begin{array}{c}\text { Antenna input } \\
\text { (dBm) }\end{array}$ & No. of CFU \\
\hline \multirow{4}{*}{ E. coli } & Control & 3.0 & - & - & $150 \times 10^{6}$ \\
\cline { 2 - 6 } & $0.5 \mathrm{GHz}$ & 3.0. & 30 & 20 & $130 \times 10^{6}$ \\
\cline { 2 - 6 } & $0.9 \mathrm{GHz}$ & 3.0 & 30 & 20 & $120 \times 10^{6}$ \\
\cline { 2 - 6 } & $1.9 \mathrm{GHz}$ & 3.0 & 30 & 20 & $200 \times 10^{6}$ \\
\cline { 2 - 6 } & $2.4 \mathrm{GHz}$ & 3.0 & 30 & 20 & $230 \times 10^{6}$ \\
\cline { 2 - 6 } & $3.0 \mathrm{GHz}$ & 3.0 & 30 & 20 & $220 \times 10^{6}$ \\
\cline { 2 - 6 } & $3.8 \mathrm{GHz}$ & 3.0 & 30 & $20 \times 10^{6}$ \\
\hline
\end{tabular}




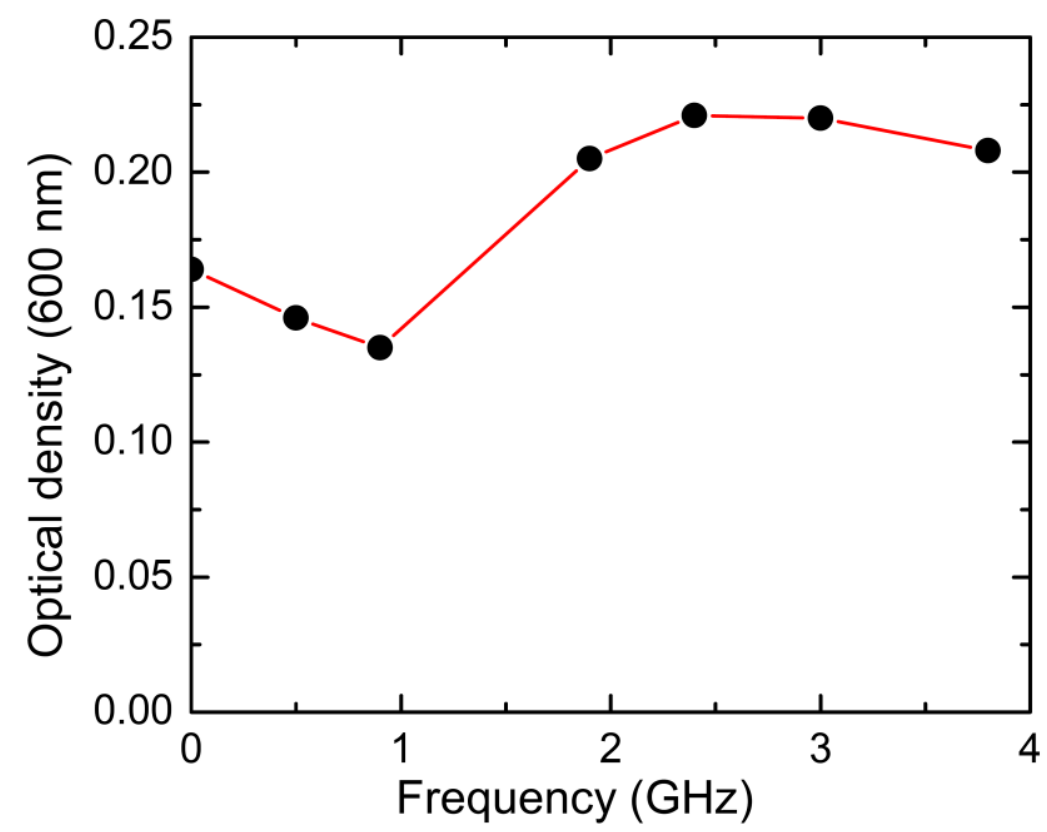

Fig 1:- Graphical illustration showing the changes of OD of E.coli suspension after being exposed to different frequencies of radiations as designed in our experiment.

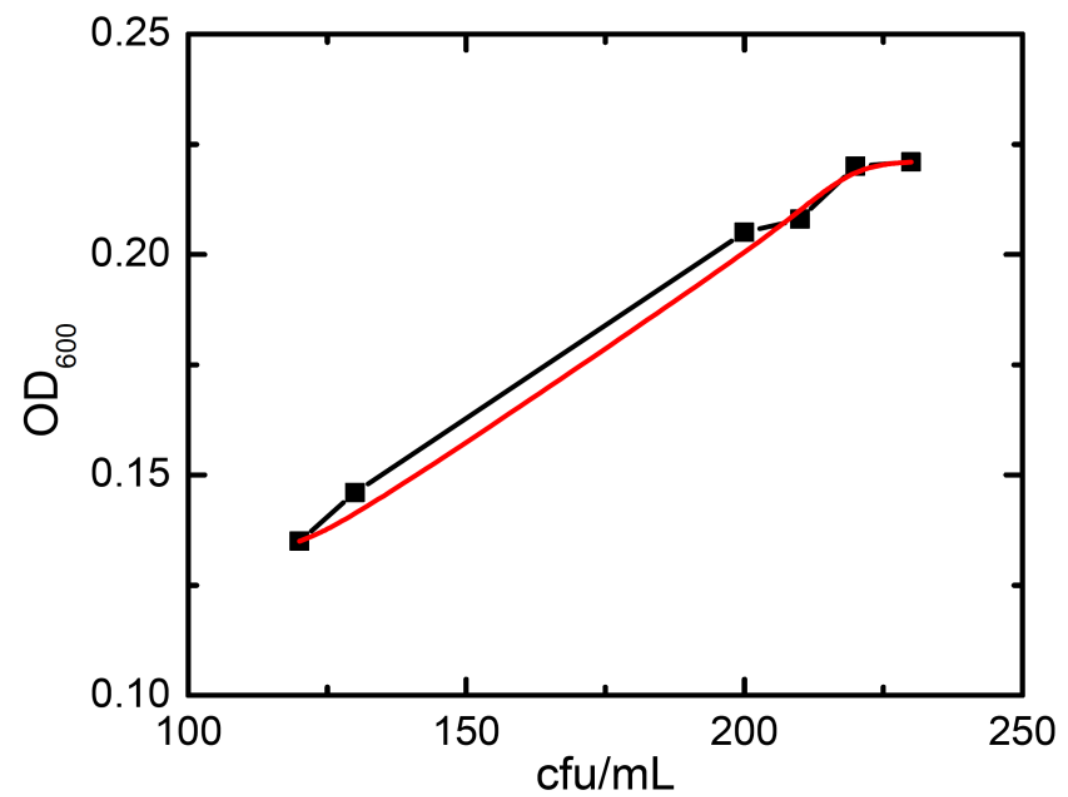

Fig 2:- Figure showing coincidence in growth pattern expressed in terms of CFU/ml and optical density (OD).[Red line represents theoretical expression of $\mathrm{CFU} / \mathrm{ml}$ and Black line represents experimental data of $\mathrm{CFU} / \mathrm{ml}$. 

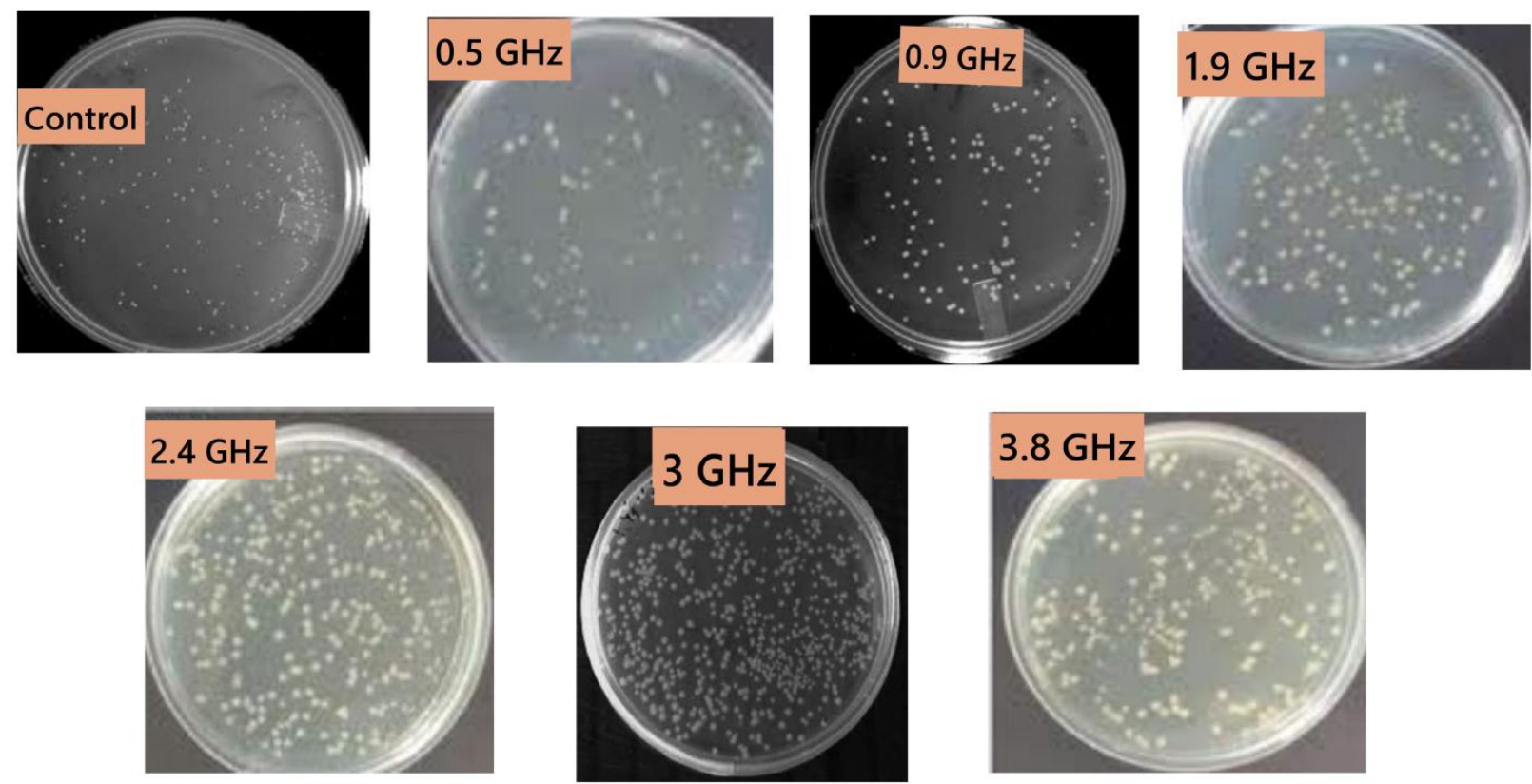

Fig 3 : Photographic representation of CFU of E. coli after exposition of radiation of different frequencies.

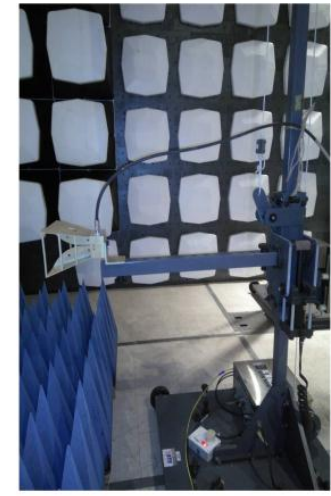

(a)

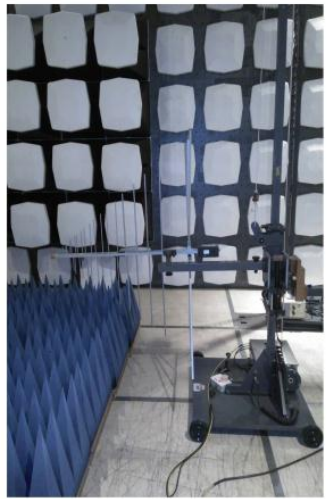

(b)

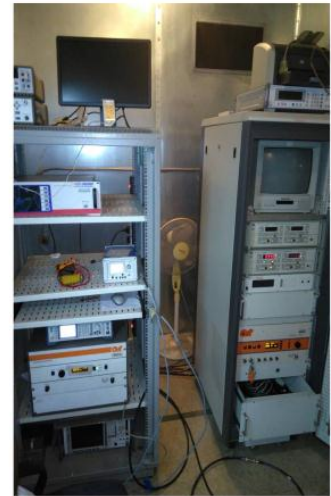

(c)

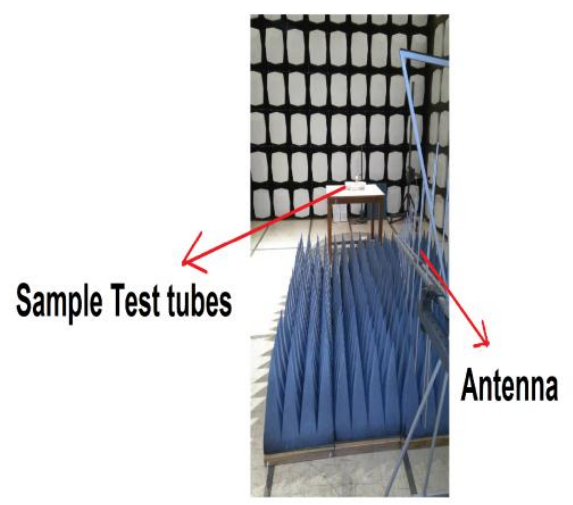

(d)

Fig4:-(a) Horn antenna used for irradiation, (b) Biconilog antenna used for irradiation, (c) Regulatory devices for controlling frequencies and power of the radiation and (d) Bacterial sample under exposition to radiation.

\section{Acknowledgement:-}

Authors are grateful to Dipankar Dan, Scientist, Society for Applied Microwave Electronics Engineering and Reserch (SAMEER), Kolkata, for his kind help and cooperation to irradiate the bacterial sample by providing all sorts of infrastructural facilities available in the Institution.

\section{Conflict of Interest:-}

Conflict of interest declared none 


\section{Reference:-}

1. Banik SB, Bandyopadhyay S, Ganguly S. Bioeffects of microwave-a brief review. Bioresource technol. 2003 Apr 30;87(2):155-9.

2. 53. Janković SM, Milošev MZ, Novaković ML. The effects of microwave radiation on microbial cultures. Hospital Pharmacology- IntMultidiscip Res J.. 2014;1(2):102-8.

3. Shamis Y, Taube A, Mitik-Dineva N, Croft R, Crawford RJ, Ivanova EP. Specific electromagnetic effects of microwave radiation on Escherichia coli. Appl. Environ. Microbiol. 2011 May 1;77(9):3017-22.

4. Tadevosian A, Kalantarian V, Trchunian A. The effects of electromagnetic radiation of extremely high frequency and low intensity on the growth rate of bacteria Escherichia coli and the role of medium pH.Biofizika. 2006 Dec;52(5):893-8.

5. Akbal A, Balik HH. Investigation of antibacterial effects of electromagnetic waves emitted by mobile phones. Pol. J. Environ. Stud.. 2013 Jan 1;22(6).

6. Berg MB. Are mobile phones harmful? ActaOncol. 2000 Jan 1;39(8):927-30.

7. Ponne CT, Bartels PV. Interaction of electromagnetic energy with biological material-relation to food processing. Radiat. Phys. Chem.1995 Apr 1;45(4):591-607.

8. Meyer, Patrícia Froes, et al. "Cellular and molecular effects of electromagnetic radiation and sonic waves." S. Afr. J. Sci. 109.7-8 (2013): 01-04.

9. Hunt RW, Zavalin A, Bhatnagar A, Chinnasamy S, Das KC. Electromagnetic biostimulation of living cultures for biotechnology, biofuel and bioenergy applications. Int J Mol Sci. 2009 Oct 23;10(10):4515-58.

10. Janković SM, Milošev MZ, Novaković ML. The effects of microwave radiation on microbial cultures. Hospital Pharmacology- IntMultidiscip Res J.. 2014;1(2):102-8.

11. Ahmed I, Istivan T, Cosic I, Pirogova E. Evaluation of the effects of extremely low frequency (ELF) pulsed electromagnetic fields (PEMF) on survival of the bacterium Staphylococcus aureus. EPJ Nonlinear Biomed Phys. 2013 Sep 9;1(1):5.

12. Woo IS, Rhee IK, Park HD. Differential damage in bacterial cells by microwave radiation on the basis of cell wall structure. Appl. Environ. Microbiol. 2000 May 1; 66(5):2243-7.

13. Soukos NS, Ximenez-Fyvie LA, Hamblin MR, Socransky SS, Hasan T. Targeted antimicrobial photochemotherapy. Antimicrobial Agents and Chemotherapy. 1998 Oct 1;42(10):2595-601.

14. Shamis Y, Taube A, Mitik-Dineva N, Croft R, Crawford RJ, Ivanova EP. Specific electromagnetic effects of microwave radiation on Escherichia coli. Applied and environmental microbiology. 2011 May 1;77(9):3017-22. 